\title{
Biology and conservation of freshwater bivalves: past, present and future perspectives
}

\author{
Manuel Lopes-Lima • Amílcar Teixeira • \\ Elsa Froufe • Anabela Lopes • Simone Varandas • \\ Ronaldo Sousa
}

Received: 16 March 2014/ Accepted: 26 April 2014/Published online: 16 May 2014

(C) Springer International Publishing Switzerland 2014

\begin{abstract}
Freshwater bivalves have been highly threatened by human activities, and recently their global decline has been causing conservational and social concern. In this paper, we review the most important research events in freshwater bivalve biology calling attention to the main scientific achievements. A great bias exists in the research effort, with much more information available for bivalve species belonging to the Unionida in comparison to other groups. The same is true for the origin of these studies, since the publishing pattern does not always correspond to the hotspots of biodiversity but is
\end{abstract}

Guest editors: Manuel P. M. Lopes-Lima, Ronaldo G. Sousa, Simone G. P. Varandas, Elsa M. B. Froufe \& Amílcar A.

T. Teixeira / Biology and Conservation of Freshwater Bivalves

M. Lopes-Lima · A. Lopes

ICBAS-UP - Abel Salazar Biomedical Sciences Institute, University of Porto, Rua de Jorge Viterbo Ferreira No. 228, 4050-313 Porto, Portugal

M. Lopes-Lima $(\bowtie) \cdot$ E. Froufe · A. Lopes · R. Sousa CIIMAR/CIMAR - Interdisciplinary Centre of Marine and Environmental Research, University of Porto, Rua dos Bragas 289, 4050-123 Porto, Portugal e-mail: lopeslima.ciimar@gmail.com

A. Teixeira

CIMO-ESA-IPB - Mountain Research Centre, School of Agriculture, Polytechnic Institute of Bragança, Campus de Santa Apolónia, Apartado 1172, 5301-854 Bragança,

Portugal concentrated in the northern hemisphere mainly in North America, Europe and Russia, with regions such as Africa and Southeast Asia being quite understudied. We also summarize information about past, present and future perspectives concerning the most important research topics that include taxonomy, systematics, anatomy, physiology, ecology and conservation of freshwater bivalves. Finally, we introduce the articles published in this Hydrobiologia special issue related with the International Meeting on Biology and Conservation of Freshwater Bivalves held in 2012 in Bragança, Portugal.

Keywords Biology · Conservation · Freshwater bivalves · Unionida

\footnotetext{
S. Varandas

CITAB-UTAD - Centre for Research and Technology of Agro-Environment and Biological Sciences, University of Trás-os-Montes and Alto Douro, Apartado 1013, 5001-811 Vila Real, Portugal

R. Sousa

CBMA - Centre of Molecular and Environmental Biology, University of Minho, Campus de Gualtar, 4710-057 Braga, Portugal
} 


\section{Important events in freshwater bivalve biology and conservation research}

Bivalves are a very important part of biodiversity playing major roles in freshwater ecosystems (Vaughn \& Hakenkamp, 2001, Howard \& Cuffey, 2006), and their global decline due to a myriad of human activities has been causing increasing concern (Lydeard et al., 2004; Strayer et al., 2004; Régnier et al., 2009).

After an initial period of species description, anatomical characterization and systematics, which started with Linnaeus in 1758 and was followed by many other notorious taxonomists and malacologists (Lamarck, Retzius, Bourguignat, Lea, Simpson, among many others), the biology of freshwater bivalves has been investigated more intensively since the end of the nineteenth century. A few landmark studies highlighting some of the most important events in freshwater bivalve biology and conservation are described in Fig. 1. The elucidation of the host relationship with fishes began with van Leeuwenhoek's description of the Unionidae larvae (glochidia) in 1697, and after nearly two centuries of intermittent controversy, culminated in several German studies (e.g. Leydig, 1866; Forel, 1866; Schierholz, 1889) that described the relationship in some detail (revised in Watters, 1994). The end of the nineteenth and beginning of the twentieth century was also an important period of research since it was the beginning of freshwater mussel life history and propagation studies at the Fairport Biological Station on the Mississippi River, Fairport, Iowa, United States of America (USA). This was the first concerted, government-funded effort focused on the study of mussel ecology and propagation in North America and perhaps in the world. Information about host relationships, feeding behaviour, habitat requirements and realization of a long to very long life span and many other aspects of mussel ecology generated by the Fairport Biological Station formed the bulk of available ecological knowledge until the 1980s. Indeed, the propagation techniques used still form the basis of today's methods. Station personnel incorporated some of the first vocal advocates for mussel conservation, which included notable researchers such as Winterton C. Curtis, George Lefevre, Robert E. Coker, Thaddeus Surber, Arthur D. Howard and Max M. Ellis, producing a vast bibliography (e.g. Lefevre and Curtis, 1910;
Coker et al., 1921; Howard, 1921). During the same period, Arnold Ortmann began a series of studies on the systematic analysis of anatomy, shell morphology and life history traits within the order Unionida (e.g. Ortmann, 1911, 1912, 1920, 1921). Ortmann was the first to synthesize this information into an evolutionary framework; he provided extensive ecological observations about mussels which, together with Charles $\mathrm{T}$. Simpson, were instrumental in stabilizing mussel nomenclature (Ortmann, 1912; Simpson, 1914). Along with the Fairport Biological Station researchers, Ortmann was one of the first biologists to call attention to the rapid decline in freshwater bivalve diversity and abundance (see Ortmann, 1909). Later in the middle of the twentieth century, Fritz Haas used a combination of reproductive, anatomical and shell morphological characters to produce a global synthesis of freshwater mussel (Unionida) systematics, which was used as a key reference until the advent of recent molecular techniques (Haas, 1940, 1969). During the second half of the twentieth century, some important publications on the description and anatomy of regional faunas were occasionally produced in some parts of the World, e.g. McMichael \& Hiscock (1958) in Australia, Van Damme (1984), MandahlBart (1988) and Daget (1998) in Africa, Brandt (1974), Liu et al., (1979) and Subba Rao (1989) in Asia and Parodiz \& Bonetto (1963) in South America. Despite the early warnings calling attention for extensive declines, the first listing of freshwater bivalves under the US Endangered Species Act just appeared in 1976, and was followed by the European Bern Convention (1979) and the Habitats Directive (1992). The initial listing of mussel species brought the global mussel extinction crisis to the attention of the conservation movement and the public at large. Critically, these events provided impetus and funding for an explosion in mussel ecology research that began in the late 1970s and continues to the present day, mainly in North America. At the same time, the establishment of the first modern, long-term academic research programs on mussel ecology by Richard J. Neves (Virginia Polytechnic and State University, USA), David L. Strayer (Cary Institute of Ecosystem Studies, USA) and Gerhard Bauer (University of Bayreuth, Germany), among others, produced numerous important publications and trained a great number of graduate students, which now lead their own research projects and provided models and support 
Fig. 1 Chronogram of the most important research events (above the year scale) and publications (below the year scale) on freshwater bivalves

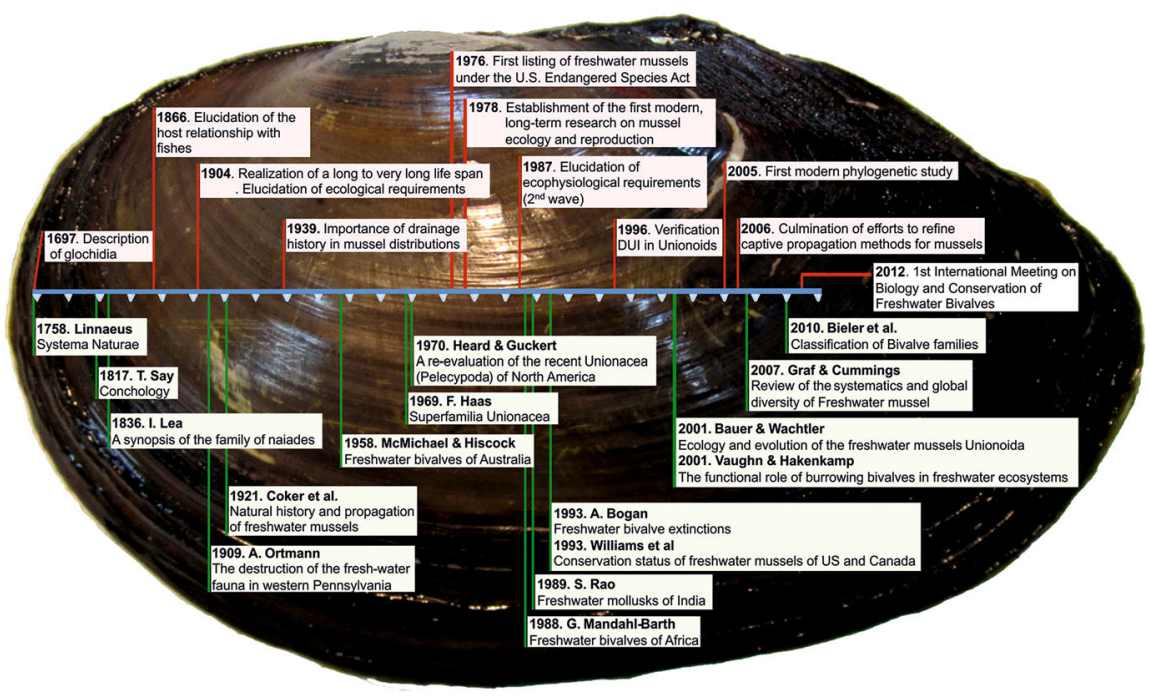

for establishment of subsequent research programs. These scientific projects soon accumulated enough critical expertise, which culminated in some modern reviews on mussel biology and ecology such as McMahon (1991), Bauer \& Wächtler (2001), Strayer (2008) and Haag (2012). The American Malacological Union (now Society) had a committee on the Common and Scientific Names of Mollusks that developed a list of all mollusc species of North America, including freshwater bivalves (Turgeon et al., 1988, 1998). This peer reviewed list finally created an up-to-date, reviewed list of freshwater bivalves for North America. This standardized list provided stability to the names of freshwater bivalves and allowed the increase in research without taxonomic issues. During the 1990s, the first comprehensive assessment of the conservation status of North American mussels was published (Williams et al., 1993) and a group of concerned people started to discuss the status, conservation and management of freshwater mussels, which resulted in the formation of a working group to develop the National Strategy for the Conservation of Native Freshwater Mussels in the USA (National Native Mussel Conservation Committee, 1998). The Freshwater Mollusk Conservation Society was also formed in 1998, which would lead and push freshwater bivalve conservation efforts into the twenty first century. At the beginning of the 2000s, a series of studies under the direction of Caryn Vaughn started to elucidate the functional role of bivalves and their importance to freshwater ecosystems (e.g. Vaughn \&
Hakenkamp, 2001; Spooner \& Vaughn, 2006; Vaughn $\&$ Spooner, 2006). During the same period, the first comprehensive revisions of mussel diversity based on modern phylogenetic methods were published (e.g. Roe \& Hoeh, 2003; Campbell et al., 2005; Graf \& Cummings, 2007). From the middle of the 2000s, the efforts to refine captive propagation methods for mussels resulted in the near perfection of these techniques and the feasibility of their use on a large scale (e.g., Henley et al., 2001; Barnhart, 2006; Gum et al., 2011). At the present, the exponential growth on freshwater bivalves' research, both in the field of basic biology, ecology and physiology but also on applied conservation such as habitats rehabilitation and propagation, needs to be integrated and available to all ecologists, conservation biologists and freshwater malacologists. This integration needs also to include managers, policy makers and other stakeholders to find and apply the best measures to conserve these animals and their natural habitats. The Freshwater Mollusk Conservation Society has played this role in North America, promoting research and awareness but also by organizing periodic meetings and workshops. In other parts of the world, research efforts vary and integration and knowledge exchange are needed, mainly in undeveloped countries of the Southern Hemisphere. Trying to fulfil this gap, a group of researchers planned and organized the first International Meeting on the Biology and Conservation of Freshwater Bivalves on 2012 (see below for further details). 
Fig. 2 Cumulative number of ISI Web of Science publications on freshwater bivalves by different taxonomic groups until December 31, 2012. The employed search terms correspond to all of the valid Freshwater Bivalve genera names + synonyms following Graf \& Cummings (2013)

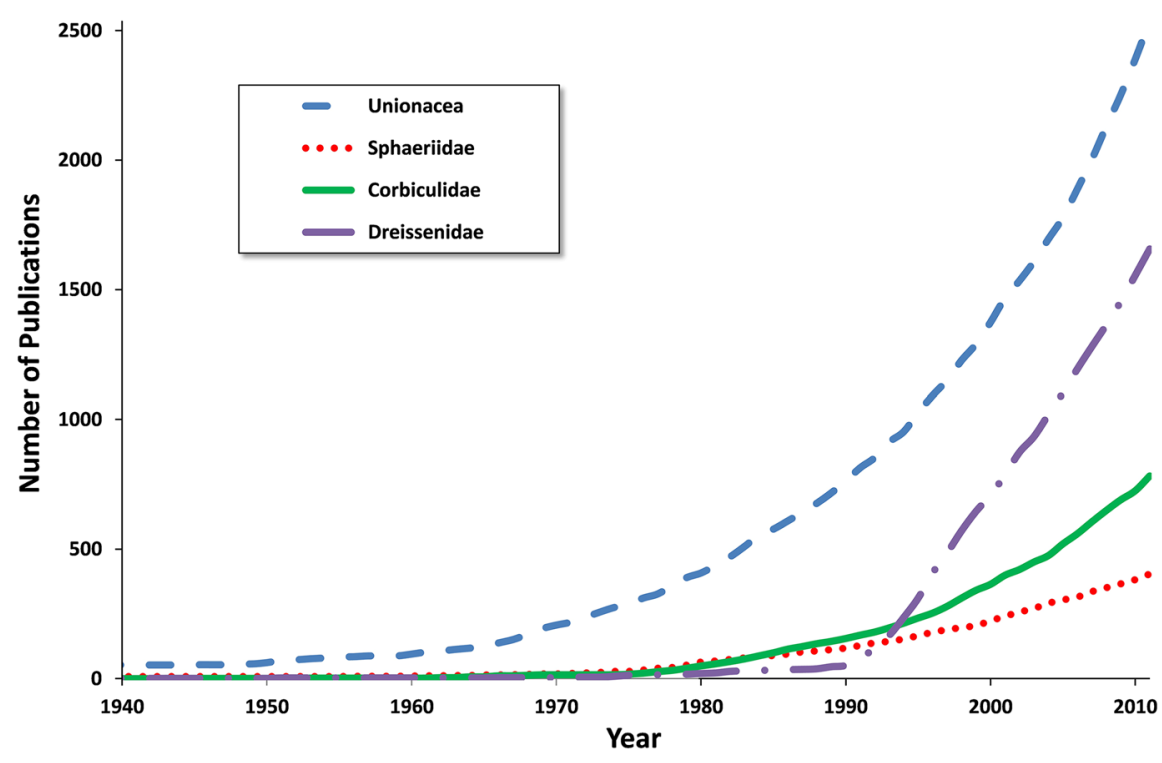

\section{Freshwater bivalves research efforts with emphasis on Unionida bivalves}

Currently, six orders of bivalves are represented in freshwater ecosystems: Arcida Gray, 1854; Cardiida Férussac, 1822; Mytilida Férussac, 1822; Pholadida Gray, 1854; Solenida Dall, 1889 and Unionida Gray, 1854 (Bogan, 2008; Graf, 2013). However, only the Unionida and Cardiida had extensive radiations, the first with six modern families in about 800 species and the latest with two big families: Sphaeriidae $(\approx 220$ spp.) and Cyrenidae (=Corbiculidae) ( $\approx 90$ spp.). The remaining five Cardiida families, together with the remaining orders, have only a few species each (Bogan, 2008; Graf, 2013).

Since the beginning of the nineteenth century, research efforts have been more focused in the larger and conspicuous Unionida, followed on a smaller scale by the also widespread Sphaeriidae family (Fig. 2). This trend has changed recently due to the proliferation of studies with invasive bivalves such as Corbicula fluminea, Dreissena polymorpha and Dreissena bugensis (Fig. 2).

Due to the high conservation value and threatened status of most Unionida mussels and the fact that invasive bivalves are thoroughly revised within the present Hydrobiologia special issue (Sousa et al., 2014) most of the present paper will focus on the Unionida.

Mussels from the Unionida order are present in all continents, except Antarctica, with two major diversity hotspots recognized in Southeast North America and Southeast Asia (Fig. 3a) (Graf \& Cummings, 2007; Bogan, 2008). As expected, and pointed out before for other organisms (e.g. Harris \& Froufe, 2005), the publishing pattern on Unionida mussels research does not always correspond to the hotspots of biodiversity but is concentrated in the northern hemisphere, mainly in North America, Europe and Russia (Fig. 3b). Regions like Africa and Southeast Asia remain quite unstudied. However, we should take in account that our assessments are just based on the ISI published papers, which may introduce some bias since ISI does not take into account grey literature.

The main research topic studied until the middle of the twentieth century was taxonomy (Fig. 4). It started at the middle of the eighteenth century with the publication of Linnaeus Systema Naturae in 1758, where some freshwater bivalves were classified with some marine species under the genus Mya. Following works, mainly performed by European and North American malacologists, addressed the taxonomy and systematics of this diverse faunal group based on conchological, anatomical and physiological characteristics. After the 1900s, very few anatomical and physiological studies have been carried until 70-80 s. After this period, an increasing interest on this group resurged, mainly related to the first listing of freshwater mussels under the U.S. Endangered Species Act, which brought the global mussel extinction crisis to 

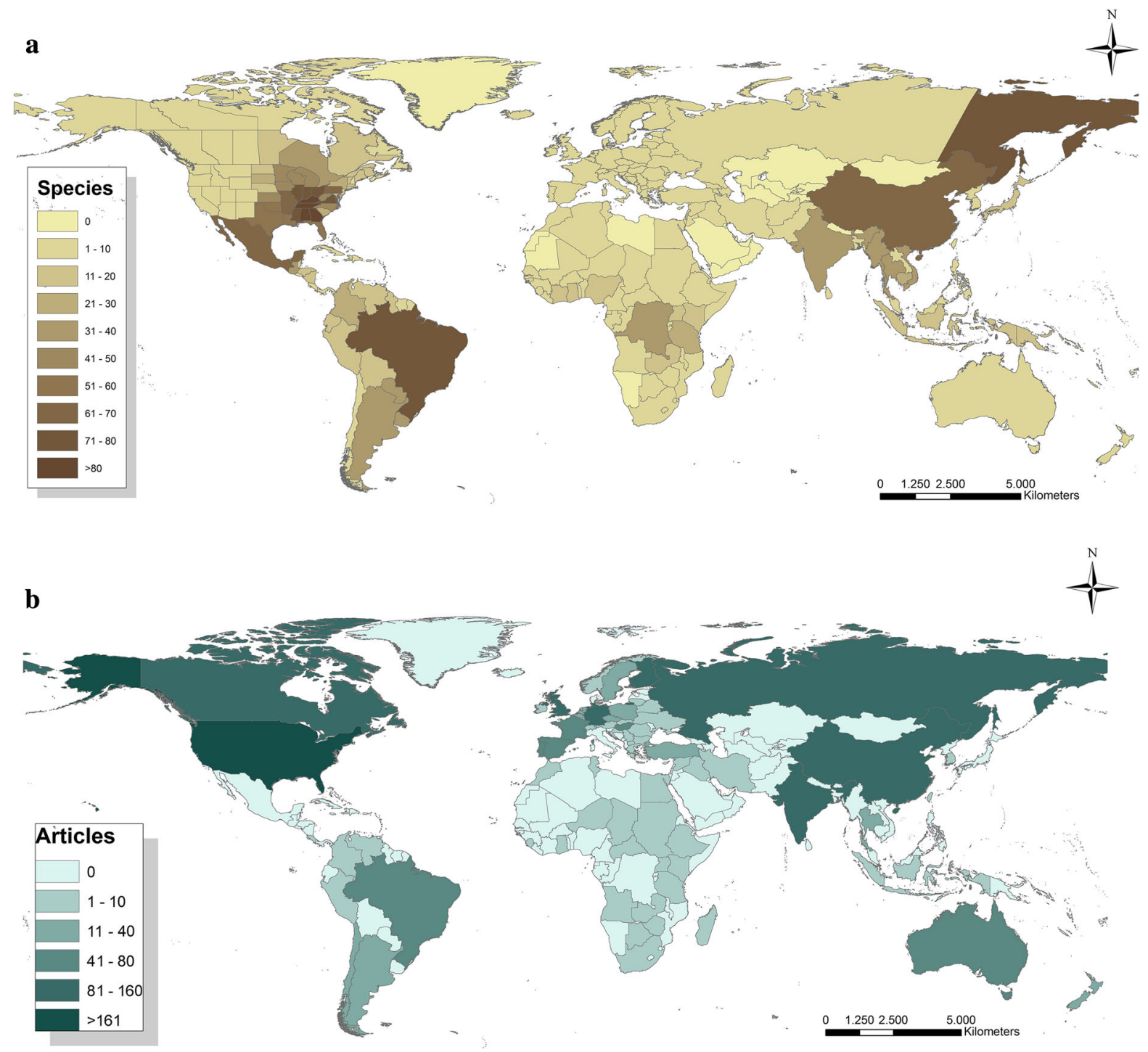

Fig. 3 a Global biodiversity of the Unionida (adapted from Cummings \& Graf, 2005). b Global distribution based on ISI Web of Science publications on freshwater bivalves by different

the attention of the scientific community (mainly in North America) and also to environmental managers and policy makers (Stansbery, 1970; Bogan, 1993; Williams et al., 1993). This critical situation in addition to the publication of the standardized peer reviewed freshwater mussel list (Turgeon et al., 1988) provided impetus and funding for an explosion in mussel research, mainly in conservation and ecology but also in physiology and toxicology that continues to taxonomic groups until December 31, 2012. The employed search terms correspond to all of the valid Freshwater Bivalve genera names + synonyms following Graf \& Cummings (2013)

the present day. In Europe, the Habitats Directive published in 1992 also promoted research on some freshwater bivalve species, which were included as important conservation targets (e.g. Margaritifera margaritifera and Unio crassus). In addition, over the last three decades, modern molecular techniques have been increasingly used for several distinct research studies but mainly related with taxonomy, phylogeny and phylogeography. 
Fig. 4 Cumulative number of ISI Web of Science publications on Unionida bivalves by different research areas. The employed search terms correspond to all of the valid freshwater bivalve genera names + synonyms following Graf \& Cummings (2013)

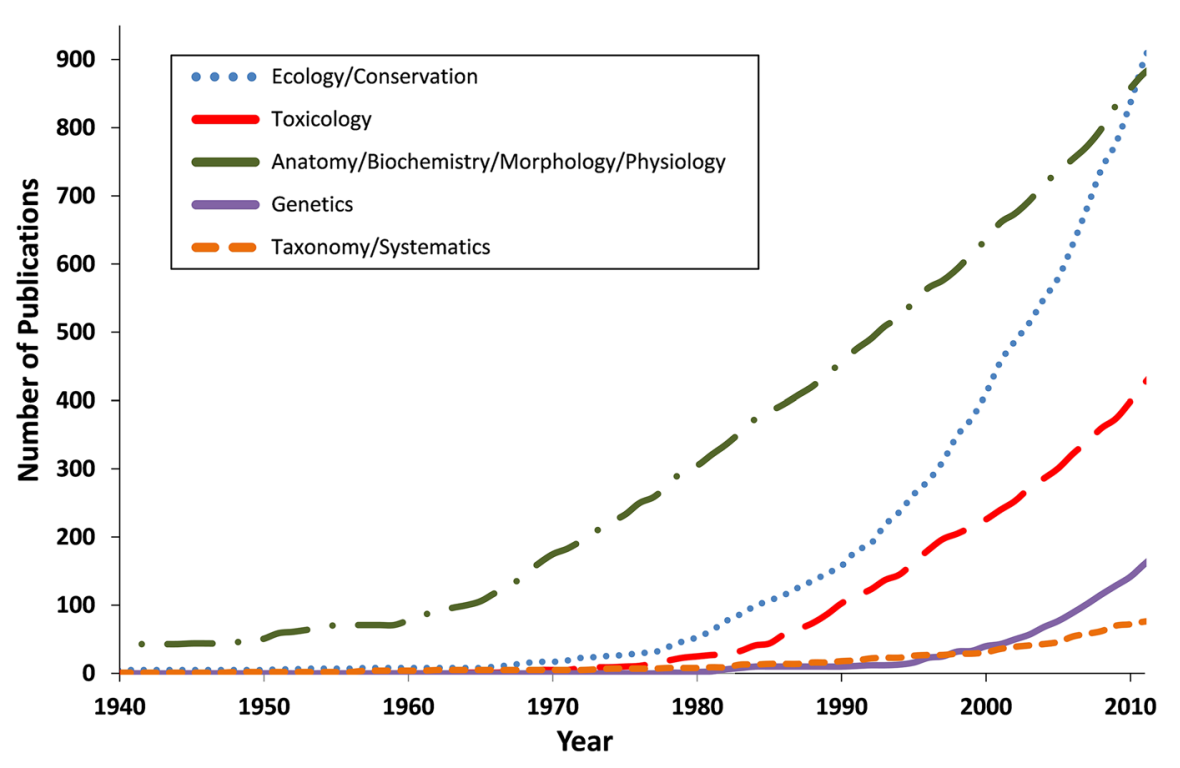

\section{Past, present and future perspectives}

Taxonomy and systematics

Soon after the publication of Systema Naturae (Linnaeus, 1758), several researchers started to delineate and revise the freshwater species into separate genus, and in 1817, Thomas Say wrote the first paper on North American freshwater bivalves by an American author. This was quickly followed by the descriptive works by Rafinesque $(1820,1831)$. These works were soon followed by the first global synopsis on Unionida (Lea, 1836, 1838, 1852, and 1870), being this information upgraded by Simpson $(1900,1914)$. The taxonomic work continued to advance with hundreds of publications, but no large comprehensive treatment occurred until Fritz Haas major monograph on the classification of the world's unionacea was completed in 1969 (Haas, 1969). Until the 1970s, the taxonomy of freshwater bivalves was based on discrete anatomical and physiological characters. In 1970, a paper combined reproductive and morphological characters in an attempt to reflect the first phylogenetic relationships among Unionida bivalves (Heard \& Guckert, 1970). Since then, the molecular techniques became increasingly used on taxonomy, systematics and phylogeny. Up to now, several different techniques have been used since the 1970s from allozymes, Restriction Fragment Length Polymorphism (RFLP) and Amplified Fragment Length Polymorphism (AFLP) to classical Sanger sequencing and microsatellite markers and more recently to the high outputs resulting from the new generation sequencing techniques. The rapid development of molecular techniques is also reflected in the publication record from the last 40 years. It started in the 1970s and 1980s with around 12 studies using allozyme profiling. The number of papers increased to about 30 in the 1990s, where this technique started to be replaced by sequencing, mainly using mtDNA markers. From the 2000s up to 2012, microsatellite markers were introduced to the study of freshwater bivalves and the total number of studies rise to about 140 , where sequencing techniques clearly dominate with almost half, followed by microsatellite with almost a quarter. Although taxonomy, phylogeny, genetic diversity and phylogeography have been the main studied areas using these techniques, they have also been applied to other fields such as protein characterization (proteomics) and toxicology with great success. Additionally, due to a particular form of mitochondrial DNA inheritance called double uniparental inheritance (DUI) present in bivalves, since the description of this mtDNA feature in Unionida mussels (Hoeh et al., 1996; Breton et al. 2007), around 15 papers have addressed this topic in freshwater bivalves. It is also worthy to mention that although no entire genome has been sequenced to date, 26 mitochondrial genomes ( 5 male and 21 female) are already sequenced, which may be used in more accurate assessments on the 
genetic diversity patterns of freshwater bivalve species. Next-generation sequencing has also recently began to be used for both the development of new markers (O'Bryhim et al., 2012; Froufe et al., 2013) and the sequencing of massive genetic resources (e.g. Wang et al., 2012) with multiple applications (e.g. ancient DNA sequencing, proteomics including protein identification and entire genome phylogenies). Although genetics have been exponentially used since the 1970s, aiding in the taxonomy, identification of the phylogenetic relationships as well as the phylogeographical and genetic diversity patterns in many species, more research is still needed. For instance, many taxonomical problems still remain, mainly due to the high plasticity of shell morphology, which may impair an accurate identification, but also because many species have not been studied using genetic techniques. Additionally, the genetic diversity patterns as well as the phylogeography of most freshwater bivalve species, with some exceptions in North America and Europe (e.g. Machordom et al., 2003; Zanatta \& Harris, 2013), are quite unknown. Furthermore, and although some good baseline phylogenetical studies have already been produced including molecular, anatomical and physiological data (Lee \& Ó'Foighil, 2003; Gelembiuk et al., 2006; Graf \& Cummings, 2007; Bogan \& Roe, 2008; Graf, 2013), the high-order phylogeny is still uncertain. The phylogeny within most families also needs further research, not only in the poorly known groups such as the Sphaeriidae, the Iridinidae in Africa and Hyriidae and Mulleriidae (=Mycetopodidae) in Australia and South America but also the Northern Hemisphere Unionida families, where many relationships remain unresolved.

\section{Anatomy and physiology}

The basic anatomy of freshwater bivalves was established in the late nineteenth and early twentieth century, but only very few studies have been carried along the twentieth and twenty first centuries (Bogan $\&$ Roe, 2008). On the other hand, while the study of physiological functions has been neglected over the first half of the last century, since the 1950s, an increasing number of studies have been published. However, most of physiological studies using freshwater bivalves did not have these species as a specific target but were more directed to the study of the biological processes per se. In fact, the large size and high density of some species have turned these animals very interesting as model organisms and several research groups, mainly in Europe and North America, used them to study a myriad of topics including cell thermal resistance, nervous cell structure, cell ciliary movements as well as complex biochemical mechanisms such as the adenylate cyclase system, sperm-egg connection and biomineralization processes. Of the small number of physiological studies directed to the bivalves themselves, a few sub-areas have received the main attention such as the basic aspects of the reproductive cycle, respiration, energy allocation, acid-base and ionic regulation as well as growth mechanisms. Nevertheless, most of the fundamental biochemical processes behind those metabolic functions are still poorly understood. Additionally, most of the published papers on the nineteenth and twentieth centuries were generally carried out in a restricted number of species being the most frequently used Anodonta cygnea and Anodonta anatina in Europe, Elliptio complanata and Pyganodon grandis in North America, and Lammelidens marginalis and Sinanodonta woodiana in Asia. Since the 1970s and 1980s due to conservation purposes, this focus has shifted for a few endangered and protected species such as Margaritifera margaritifera and Unio crassus. Another applied use of freshwater bivalves is on toxicological studies. In fact, on the last decades, freshwater bivalves have been used in several ecotoxicological applications. Until recently, the smaller Cyrenidae (=Corbiculidae), Dreissenidae and Sphaeriidae, have mainly been used as preferred ecotoxicological research organisms supporting the major part of basic research on bioaccumulation, toxicokinetics and toxicity publications. On the other hand, due to the recent global decline and worldwide focus on Unionida mussels, this order has become a major study target in the field of ecotoxicology (for a recent review see Farris \& Van Hassel, 2010), mainly using the highly sensitive larvae (glochidia). Once again, most of the research does not deal with the effects on the mussel per se but is more directed to the use of these organisms as bioindicators. In summary, several physiological functions remain quite unknown in freshwater bivalves, such as the immunological system, the neuroendocrine system, ionic regulation and detoxification mechanisms. Even simple things such as maximum age, growth and age of maturity are 
unknown for most species and for unionids, we still almost ignore how the glochidia elude the fish immunological system and how the larvae are able to encyst in specific hosts. These basic aspects should be addressed in future studies.

\section{Ecology and conservation}

The number of scientific studies dealing with ecology and conservation of freshwater bivalves increased substantially in the last three decades and follows the same pattern described for other research topics (Fig. 4). Many of these studies are related with classical ecology describing the importance of abiotic factors (e.g. temperature, altitude, current velocity and nutrients) and/or biotic interactions (e.g. predation, competition, parasitism and disease) determining the spatial distribution or population structure of freshwater bivalves. However, the number of studies exploring the importance of these biotic interactions is much smaller being the exception the already considerable knowledge acquired regarding the fundamental role of fish hosts on the life cycle of Unionida bivalves. Indeed, the very unusual life cycle of freshwater mussels further complicates a full understanding of their ecology but on the other hand makes them particularly amenable for studies addressing behaviour and evolution, being this issue a very interesting line of future research (Douda et al., 2013). In relation to conservation, the most part of studies explore the main threats (e.g. loss and fragmentation of habitat, changes in river flow, pollution, overexploitation, introduction of non-native species and climate change) that are affecting this group of organisms and in the last decade, a growing number of studies have been also exploring new methods to increase our management ability (e.g. considerable insights have been gained about efficient propagation methods in Unionida mussels) to conserve these species. Nevertheless, almost all the studies concerning the conservation of freshwater bivalves have been devoted to the Unionida, and almost nothing is known about the Sphaeriidae even if these species have been also facing considerable declines in the last decades (Sousa et al., 2008, 2011a). Despite the growing number of studies, many gaps still persist about fundamental aspects such as density, biomass, growth and secondary production, the main factors (dispersal, habitat, food, enemies and hosts) determining the spatial distribution of freshwater bivalves and about quantitative studies exploring the main threats responsible for substantial declines (for a review on these factors see Strayer, 2008). Also, important is the almost non-existence of data exploring the main factors determining temporal heterogeneity, which may obscure many ecological interpretations. This temporal information can be particular important because of the long life cycle and the long history of human threats to some of these species, which can be responsible for a considerable extinction debt in freshwater bivalves (Haag, 2012). In the same vein, given the long life cycle of many species, it is expected that recovery takes decades even if appropriate management actions are applied today.

Considering that substantial gaps in knowledge still persist at the population level, it is not strange that studies exploring changes at the community and ecosystem levels mediated by freshwater bivalves are rare. Even so, freshwater bivalves are usually described as important consumers and preys in freshwater ecosystems and may represent an important energetic link between the water column and the benthos. This importance may be high, particularly in areas where these species attain a great density and biomass. Recently, and recognizing that freshwater bivalve populations have declined dramatically around the world (but data still scarce in South America, Africa and Asia), scientists are becoming more aware about the possible ecological implications of these declines. Therefore, future studies should also focus on possible changes in important functions and services mediated by freshwater bivalves. Theoretically, important alterations may include changes in phytoplankton, primary and secondary production, nutrient cycling, organic matter dynamics, benthic diversity and energy transfer between aquatic and adjacent riparian ecosystems. However, most of these changes remain speculative and illusive with very few quantitative studies. Anyway, recently, Caryn Vaughn and collaborators were able to show in a variety of empirical experiments in mesocosm or natural conditions that Unionida mussels (i) can influence ecosystem processes and functions by modifying the nutrients dynamics that limit primary productivity and dense aggregations of these bivalve species may act as biogeochemical hotspots that influence the standing crops and composition of algal species (Vaughn et al., 2007; Spooner \& Vaughn, 2008; 
Atkinson et al., 2013); (ii) can increase abundances of grazing aquatic insect larvae (Spooner \& Vaughn; 2006, Vaughn \& Spooner, 2006; Spooner et al., 2012) and (iii) can increase the flux of aquatic insect subsidies to terrestrial predators and in this way can link aquatic and adjacent riparian ecosystems (Allen et al., 2012). This last aspect has been also the focus of some studies in Europe that explore the functional importance of massive mortalities of freshwater bivalves during extreme climatic events (droughts and floods) and how the large accumulation of this biomass near the banks may be an important subsidy from aquatic to adjacent terrestrial ecosystems (Sousa et al., 2012; Bódis et al., 2014). Finally, a small number of studies also explored the importance of these species as ecosystem engineers. The physical changes mediated by freshwater bivalves, which include filtration, bioturbation and availability of shells, may have extraordinary effects, mainly when we have dense aggregations (Gutiérrez et al., 2003; Sousa et al., 2009).

Not surprisingly, and given the overall described assimilatory and non-assimilatory effects, some authors consider that freshwater bivalves may be classified as keystone species in some habitats due to their disproportional large impacts on ecosystem structure and function (Geist, 2010). Interestingly, and although some studies showed an incredible decline of these species and their consequences in ecosystem functioning, in recent years, some of these same systems have been invaded by several bivalve species. Indeed, a great number of studies using freshwater bivalves address the ecological and economic aspects related with the introduction of several non-native invasive species from the Cyrenidae (=Corbiculidae) and Dreissenidae families (Fig. 2a, b). In terms of biodiversity and ecosystem functioning theory will be important not only address possible changes in ecosystems due to loss of species but also include studies where the number of species increased due to introductions and how this translate in possible changes in ecosystem functioning (Sousa et al., 2011b; Strayer, 2012). A more comprehensive understanding in aquatic ecosystem processes and functions resulting from this biodiversity loss (via native bivalve extinctions) or gain (via invasive bivalve introductions) is just in the beginning, but promising results are becoming available and this taxonomic group is highly suitable for field and laboratory manipulations and so serving as an interesting model to assess these functional changes.

\section{The international meeting on biology and conservation of freshwater bivalves}

The international meeting on biology and conservation of freshwater bivalves was organized by the School of Agriculture of the Polytechnic Institute of Bragança, Portugal, in September 2012. This meeting was the first event held in Europe on this topic and was attended by 113 experts from 22 different countries. This meeting was an attempt, through a cycle of presentations, debates and field trips, to create a network of knowledge with the final goal of developing collaborative projects and discuss potential global directives for the protection and conservation of this important faunistic group. The first result of this meeting is the publication of this special issue in Hydrobiologia, which includes a total of 20 papers (including this introductory note). Of these 20 papers, three address general conservational aspects about freshwater bivalves in South America (Pereira et al., 2014), North America (Haag \& Williams, 2014) and Australasia (Walker et al., 2014). One paper presents the molecular phylogeny of the Unio genus in France (Prié \& Puillandre, 2014). Three papers assess the distribution of freshwater mussels and their implication for conservation at a large (Prié et al., 2014) and small (Denic et al., 2014; Zieritz et al., 2014) spatial scales and another one modelled the importance of hydraulic parameters in the distribution of the invasive species Dreissena polymorpha (Sanz-Ronda et al., 2014). Several papers (six in total) used as a model organism, the freshwater pearl mussel $M$. margaritifera and address aspects such as distribution and conservation status of this species in Russia (Makhrov et al., 2014; Popov \& Ostrovsky, 2014), host-dependent genetic variation (Karlsson et al., 2014), the physiological response of juvenile brown trout (Salmo trutta) to encystment by the parasitic larvae (Thomas et al., 2014), captive breeding techniques (Scheder et al., 2014) and the impact of land use on $M$. margaritifera and its host fish S. trutta (Österling \& Högberg, 2014); all these works may have considerable importance for the conservation of this species and generate important information that can be used in the implementation of management measures. One 
paper assesses the potential use of U. pictorum and $U$. tumidus as model organisms for genotoxicity monitoring in freshwater environments (Vuković-Gačić et al., 2014). Three papers describe possible effects of invasive bivalves one being a review discussing the impacts from the individual to the ecosystem level and discuss some possible control strategies (Sousa et al., 2014), the second quantifies the density and biomass of massive mortalities of invasive bivalve species after extreme climatic events and decribes how this can result in a trophic subsidy to the adjacent terrestrial ecosystems (Bódis et al., 2014) and a third paper assesses the consumption of food sources and the potential competition between native (Diplodon parallelopipedon) and non-native (Corbicula fluminea) species (Marroni et al., 2014). Finally, one paper by Strayer (2014) analyses how nutrient cycles and freshwater mussels affect one another.

Although many gaps still exist about the biology of freshwater bivalves, information will be always our best ally to conserve these fascinating creatures, and we hope that the studies contained in this special issue increase our ability to found new ways to protect these species from extinction and restore their habitat.

Acknowledgments We would like to express our gratitude to our sponsors and institutions, especially to the Polytechnic Institute of Bragança for all the logistic support. We acknowledge all keynote speakers, authors, session chairpersons and especially to all attendees whose contributions were fundamental for the success of this meeting. We would also like to thank all referees of this special issue and to Koen Martens, Editor-in-Chief of Hydrobiologia, for all the valuable comments and suggestions. The chronogram was built with the help of the expert opinion of fellow colleagues Rafael Araujo, Arthur Bogan, Kevin Cummings, Dan Graf, Wendell Haag, Karl-Otto Nagel and David Strayer to whom we are very grateful. The authors acknowledge the support provided by Portuguese Foundation for Science and Technology (FCT) and COMPETE funds-projects CONBI (Contract: PTDC/AACAMB/117688/2010) and ECO-IAS (Contract: PTDC/AAC$\mathrm{AMB} / 116685 / 2010)$, and by the European Regional Development Fund (ERDF) through the COMPETE, under the project "PEst-C/MAR/LA0015/2011".

\section{References}

Allen, D. C., C. C. Vaughn, J. F. Kelly, J. T. Cooper \& M. H. Engel, 2012. Bottom-up biodiversity effects increase resource subsidy flux between ecosystems. Ecology 93: 2165-2174.

Atkinson, C. L., C. C. Vaughn, K. J. Forshay \& J. T. Cooper, 2013. Aggregated filter feeding consumers alter nutrient limitation - consequences for ecosystem and community dynamics. Ecology 94: 1359-1369.

Barnhart, M. C., 2006. Buckets of muckets: a compact system for rearing juvenile freshwater mussels. Aquaculture 254: 227-233.

Bauer, G. \& K. Wächtler, 2001. Ecology and Evolution of the Freshwater Mussels Unionoida, Vol. 145. Springer, Berlin.

Bódis, E., B. Tóth \& R. Sousa, 2014. Massive mortality of invasive bivalves as a potential resource subsidy for the adjacent terrestrial food web. Hydrobiologia. doi:10.1007/ s10750-013-1445-5.

Bogan, A. E., 1993. Freshwater bivalve extinctions (Mollusca: Unionoida): a search for causes. American Zoologist 33: 599-609.

Bogan, A. E., 2008. Global diversity of freshwater mussels (Mollusca, Bivalvia) in freshwater. Hydrobiologia 595: 139-147.

Bogan, A. E. \& K. J. Roe, 2008. Freshwater bivalve (Unioniformes) diversity, systematics, and evolution: status and future directions. Journal of the North American Benthological Society 27: 349-369.

Breton, S., H. D. Beaupre, D. T. Stewart, W. R. Hoeh \& P. U. Blier, 2007. The unusual system of doubly unipartental inheritance of mtDNA: isn'st one enough. Trends in Genetics 23: 465-474.

Brandt, R. A. M., 1974. The non-marine aquatic Mollusca of Thailand. Archiv für Molluskenkunde 105: 1-423.

Campbell, D. C., J. M. Serb, J. E. Buhay, K. J. Roe, R. L. Minton \& C. Lydeard, 2005. Phylogeny of North American amblemines (Bivalvia, Unionoida): prodigious polyphyly proves pervasive across genera. Invertebrate Biology 124 : 131-164.

Coker, R. E., A. F. Shira, H. W. Clark \& A. D. Howard, 1921. Natural history and propagation of freshwater mussels. Bulletin of the United States Bureau of Fisheries 37: 75-181.

Cummings, K. S. \& D. L. Graf, 2005. Global distribution of freshwater mussel diversity. In Poster presentation, Meeting of the Freshwater Mollusk Conservation Society, 15-18 May 2005, St. Paul, Minnesota.

Daget, J., 1998. Catalogue raisonné des mollusques bivalves d'eau douce africains. Backhuys Publishers, Leiden and OSTROM, Paris.

Denic, M., K. Stoeckl, B. Gum \& J. Geist, 2014. Physicochemical assessment of Unio crassus habitat quality in a small upland stream and implications for conservation. Hydrobiologia. doi:10.1007/s10750-013-1467-z.

Douda, K., M. Lopes-Lima, M. Hinzmann, J. Machado, S. Varandas, A. Teixeira \& R. Sousa, 2013. Biotic homogenization as a threat to native affiliate species: fish introductions dilute freshwater mussels's resources. Diversity and Distributions 19: 933-942.

European Bern Convention, 1979. Convention on the Conservation of European Wildlife and Natural Habitats. 19.IX.1979, Council of Europe, Bern.

Farris, J. L., and J. H. Van Hassel (eds) (2010). Freshwater Bivalve Ecotoxicology. CRC Press, Boca Raton.

Forel, F. A., 1866. Einige Beobachtungen über die Entwicklund des zelligen Muskelgewebes. Beiträge zur Entwicklungsgeschichte der Najaden. Inaugural-Abhandlung der medicinischen Facultät zu Wurzburg, Wurzburg. 
Froufe, E., C. Sobral, A. Teixeira, A. Lopes, R. Sousa, S. Varandas \& M. Lopes-Lima, 2013. Development and multiplexing of microsatellite loci for the near threatened freshwater mussel Potomida littoralis (Cuvier, 1798) using 454 sequencing. Aquatic Conservation: Marine and Freshwater Ecosystems 23: 619-623.

Geist, J., 2010. Strategies for the conservation of endangered freshwater pearl mussels (Margaritifera margaritifera L.): a synthesis of conservation genetics and ecology. Hydrobiologia 644: 69-88.

Gelembiuk, G. W., G. E. May \& C. E. Lee, 2006. Phylogeography and systematics of zebra mussels and related species. Molecular Ecology 15: 1033-1050.

Graf, D. L., 2013. Patterns of freshwater bivalve global diversity and the state of phylogenetic studies on the Unionoida, Sphaeriidae, and Cyrenidae. American Malacological Bulletin 31: 135-153.

Graf, D. L. \& K. S. Cummings, 2007. Review of the systematics and global diversity of freshwater mussel species (Bivalvia: Unionoida). Journal of Molluscan Studies 73: 291-314.

Graf, D. L. \& K. S. Cummings, 2013. The Mussel Project Website [Available at http://mussel-project.uwsp.edu/]. Accessed 1 March 2014.

Gum, B., M. Lange \& J. Geist, 2011. A critical reflection on the success of rearing and culturing juvenile freshwater mussels with a focus on the endangered freshwater pearl mussel (Margaritifera margaritifera L.). Aquatic Conservation: Marine and Freshwater Ecosystems 21: 743-751.

Gutiérrez, J. L., C. G. Jones, D. L. Strayer \& O. O. Iribarne, 2003. Mollusks as ecosystem engineers: the role of shell production in aquatic habitats. Oikos 101: 79-90.

Haag, W. R., 2012. North American freshwater mussels: natural history, ecology, and conservation. Cambridge University Press, Cambridge.

Haag, W. R. \& J. D. Williams, 2014. Biodiversity on the brink: an assessment of conservation strategies for North American freshwater mussels. Hydrobiologia. doi:10.1007/ s10750-013-1524-7.

Haas, F., 1940. A tentative classification of the palearctic unionids. Zoological Series of Field Museum of Natural History 24: 115-141.

Haas, F., 1969. Superfamilia Unionacea. Das Tierreich, Vol. 88. De Gruyter, Berlin.

Habitats Directive, 1992. Council of Europe Directive 92/43/ EEC of 21 May 1992 on the conservation of natural habitats and of wild fauna and flora. Brussels, Belgium.

Harris, D. J. \& E. Froufe, 2005. Taxonomic Inflation: species concept or historical geopolitical bias? Trends in Ecology and Evolution 20: 6-7.

Heard, W. H. \& R. H. Guckert, 1970. A re-evaluation of the recent Unionacea (Pelecypoda) of North America. Malacologia 10: 333-355.

Henley, W. F., L. L. Zimmerman \& R. J. Neves, 2001. Design and evaluation of recirculating water systems for maintenance and propagation of freshwater mussels. North American Journal of Aquaculture 63: 144-155.

Hoeh, W. R., D. T. Stewart, B. W. Sutherland \& E. Zouros, 1996. Multiple origins of gender-associated mitochondrial DNA lineages in bivalves (Mollusca: Bivalvia). Evolution 50: 2276-2286.
Howard, A. D., 1921. Experiments in the culture of fresh-water mussels. Bulletin of the US Bureau of Fisheries 38: 63-90.

Howard, J. K. \& K. M. Cuffey, 2006. The functional role of native freshwater mussels in the fluvial benthic environment. Freshwater Biology 51: 460-474.

Karlsson, S., B. M. Larsen \& K. Hindar, 2014. Host-dependent genetic variation in freshwater pearl mussel (Margaritifera margaritifera L.). Hydrobiologia. doi:10.1007/s10750013-1679-2.

Lea, I., 1836. A Synopsis of the Family of Naiades, 1st ed. Pennsylvania, Philadelphia.

Lea, I., 1838. A Synopsis of the Family of Naiades, 2nd ed. Pennsylvania, Philadelphia.

Lea, I., 1852. A Synopsis of the Family of Naiades, 3rd ed. Pennsylvania, Philadelphia.

Lea, I., 1870. A Synopsis of the Family Unionidae, 4th ed. Pennsylvania, Philadelphia.

Lee, T. \& D. Ó' Foighil, 2003. Phylogenetic structure of the Sphaeriinae, a global clade of freshwater bivalve molluscs, inferred from nuclear (ITS-1) and mitochondrial (16S) ribosomal gene sequences. Zoological Journal of the Linnean Society 137: 245-260.

Lefevre, G. \& W. C. Curtis, 1910. Reproduction and parasitism in the Unionidae. Journal of Experimental Zoology 9: 79-116.

Leydig, F., 1866. Mittheilung über den Parasitismus junger Unioniden an Fischen in Noll. Tübingen, Inaugural-Dissertation, Frankfurt am Main.

Linnaeus, C., 1758. Systema Naturae per Regna Tria Naturae. Salvii, Stockholm.

Liu, Y. Y., W. Z. Zhang, Y. X. Wang \& E. Y. Wang, 1979. Economic fauna of China (freshwater mollusks). Science press, Beijing.

Lydeard, C., R. H. Cowie, W. F. Ponder, A. E. Bogan, P. Bouchet, S. A. Clark, K. S. Cummings, T. J. Frest, O. Gargominy, D. G. Herbert, R. Hershler, K. E. Perez, B. Roth, M. Seddon, E. E. Strong \& F. G. Thompson, 2004. The global decline of non-marine mollusks. BioScience 54: 321-330.

Machordom, A., R. Araujo, D. Erpenbeck \& M. Á. Ramos, 2003. Phylogeography and conservation genetics of endangered European Margaritiferidae (Bivalvia: Unionoidea). Biological Journal of the Linnean Society 78: 235-252.

Makhrov, A., J. Bespalaya, I. Bolotov, I. Vikhrev, M. Gofarov, Y. Alekseeva \& A. Zotin, 2014. Historical geography of pearl harvesting and current status of populations of freshwater pearl mussel Margaritifera margaritifera $(\mathrm{L}$.) in the western part of Northern European Russia. Hydrobiologia. doi:10.1007/s10750-013-1546-1.

Mandahl-Barth, G., 1988. Studies on African Freshwater Bivalves. Danish Bilharzias Laboratory, Charlottenlund.

Marroni, S., C. Iglesias, N. Mazzeo, J. Clemente, F. Teixeira de Mello \& J. P. Pacheco, 2014. Alternative food sources of native and non-native bivalves in a subtropical eutrophic lake. Hydrobiologia. doi:10.1007/s10750-013-1714-3.

McMahon, R. F., 1991. Mollusca: Bivalvia. In Thorp, J. H. \& A. P. Covich (eds), Ecology and Classification of North American Freshwater Invertebrates. Academic Press, San Diego CA: 315-399.

McMichael, D. F. \& I. D. Hiscock, 1958. A monograph of the freshwater mussels (Mollusca: Pelecypoda) of the 
Australian region. Australian Journal of Marine and Freshwater Research 9: 372-508.

National Native Mussel Conservation Committee, 1998. National strategy for the conservation of native freshwater mussels. Journal of Shellfish Research 17: 1419-1428.

O’Bryhim, J., J. P. Chong, S. L. Lance, K. L. Jones \& K. J. Roe, 2012. Development and characterization of sixteen microsatellite markers for the federally endangered species: Leptodea leptodon (Bivalvia: Unionidae) using paired-end Illumina shotgun sequencing. Conservation Genetics Resources 4: 787-789.

Ortmann, A. E., 1909. The destruction of the fresh-water fauna in western Pennsylvania. Proceedings of the American Philosophical Society 48: 90-110.

Ortmann, A. E., 1911. A monograph of the naiades of Pennsylvania. Parts I and II. Memoirs of the Carnegie Museum 4: 279-347.

Ortmann, A. E., 1912. Notes upon the families and genera of the najades. Annals of the Carnegie Museum 8: 222-365.

Ortmann, A. E., 1920. Correlation of shape and station in freshwater mussels (Naiades). Proceedings of the American Philosophical Society 59: 269-312.

Ortmann, A. E., 1921. The anatomy of certain mussels from the Upper Tennessee. The Nautilus 34: 81-91.

Österling, M. \& J.-O. Högberg, 2014. The impact of land use on the mussel Margaritifera margaritifera and its host fish Salmo trutta. Hydrobiologia. doi:10.1007/s10750-0131501-1.

Parodiz, J. J. \& A. A. Bonetto, 1963. Taxonomy and zoogeographic relationships of the South American naiades (Pelecypoda: Unionacea and Mutelacea). Malacologia 1: 179-213.

Pereira, D., M. C. D. Mansur, L. D. S. Duarte, A. Schramm de Oliveira, D. M. Pimpão, C. T. Callil, C. Ituarte, E. Parada, S. Peredo, G. Darrigran, F. Scarabino, C. Clavijo, G. Lara, I. C. Miyahira, M. T. R. Rodriguez \& C. Lasso, 2014. Bivalve distribution in hydrographic regions in South America: historical overview and conservation. Hydrobiologia. doi:10.1007/s10750-013-1639-x.

Popov, I. Y. \& A. N. Ostrovsky, 2014. Survival and extinction of the southern populations of freshwater pearl mussel Margaritifera margaritifera in Russia (Leningradskaya and Novgorodskaya oblast). Hydrobiologia. doi:10.1007/ s10750-013-1640-4.

Prié, V. \& N. Puillandre, 2014. Molecular phylogeny, taxonomy, and distribution of French Unio species (Bivalvia, Unionidae). Hydrobiologia. doi:10.1007/s10750-013-1571-0.

Prié, V., Q. Molina \& B. Gamboa, 2014. French naiad (Bivalvia: Margaritiferidae, Unionidae) species distribution models: prediction maps as tools for conservation. Hydrobiologia. doi:10.1007/s10750-013-1597-3.

Rafinesque, C. S., 1820. Monographie des coquilles bivalves fluviatiles de la Rivière Ohio, contenant douze genres et soixante-huit espèces. Annales Générales des Sciences Physiques, a Bruxelles 5: 287-322.

Rafinesque, C. S., 1831. Continuation of a monograph of the bivalve shells of the River Ohio. William Sharpless, Philadelphia.

Régnier, C., B. Fontaine \& P. Bouchet, 2009. Not knowing, not recording, not listing: numerous unnoticed mollusk extinctions. Conservation Biology 23: 1214-1221.
Roe, K. J. \& W. R. Hoeh, 2003. Systematics of freshwater mussels (Bivalvia: Unionoida). In Lydeard, C. \& D. R. Lindberg (eds), Molecular systematics and phylogeography of mollusks. Smithsonian Books, Washington: 91-122.

Sanz-Ronda, F. J., S. López-Sáenz, R. San-Martín \& A. PalauIbars, 2014. Physical habitat of zebra mussel (Dreissena polymorpha) in the lower Ebro River (Northeastern Spain): influence of hydraulic parameters in their distribution. Hydrobiologia. doi:10.1007/s10750-013-1638-y.

Scheder, C., B. Lerchegger, M. Jung, D. Csar \& C. Gumpinger, 2014. Practical experience in the rearing of freshwater pearl mussels (Margaritifera margaritifera): advantages of a work-saving infection approach, survival, and growth of early life stages. Hydrobiologia. doi:10.1007/s10750-0131516-7.

Schierholz, C., 1889. Über Entwicklung der Unioniden. Denkschriften der Kaiserlichen Akademie der Wissenschaften, Mathematischnaturwissen Klasse 55: 183-214.

Simpson, C. T., 1900. Synopsis of the naiades, or pearly freshwater mussels. Proceedings of the United States National Museum 22: 501-1044.

Simpson, C. T., 1914. A descriptive catalogue of the naiades, or pearly fresh-water mussels. Parts I-III. Bryant Walker, Detroit, MI.

Sousa, R., P. Morais, C. Antunes \& L. Guilhermino, 2008. Factors affecting Pisidium amnicum (Müller, 1774; Bivalvia: Sphaeriidae) distribution in the River Minho estuary: consequences for its conservation. Estuaries and Coasts 31: 1198-1207.

Sousa, R., J. L. Gutiérrez \& D. C. Aldridge, 2009. Non-indigenous invasive bivalves as ecosystem engineers. Biological Invasions 11: 2367-2385.

Sousa, R., M. Ilarri, A. T. Souza, C. Antunes \& L. Guilhermino, 2011a. Rapid decline of the greater European peaclam at the periphery of its distribution. Annales Limnologie International Journal of Limnology 47: 211-219.

Sousa, R., P. Morais, E. Dias \& C. Antunes, 2011b. Biological invasions and ecosystem functioning: time to merge. Biological Invasions 13: 1055-1058.

Sousa, R., S. Varandas, R. Cortes, A. Teixeira, M. Lopes-Lima, J. Machado \& L. Guilhermino, 2012. Massive die-offs of freshwater bivalves as resource pulses. Annales Limnologie - International Journal of Limnology 48: 105-112.

Sousa, R., A. Novais, R. Costa \& D. L. Strayer, 2014. Invasive bivalves in fresh waters: impacts from individuals to ecosystems and possible control strategies. Hydrobiologia. doi:10.1007/s10750-012-1409-1.

Spooner, D. E. \& C. C. Vaughn, 2006. Context-dependent effects of freshwater mussels on the benthic community. Freshwater Biology 51: 1016-1024.

Spooner, D. E. \& C. C. Vaughn, 2008. A trait-based approach to species' roles in stream ecosystems: Climate change, community structure, and material cycling. Oecologia 158: 307-317.

Spooner, D. E., C. C. Vaughn \& H. S. Galbraith, 2012. Species traits and environmental conditions govern the relationship between biodiversity effects across trophic levels. Oecologia 168: 533-548.

Stansbery, D. H., 1970. Eastern freshwater mollusks. I. The Mississippi and St. Lawrence River systems. American 
Malacological Union Symposium on Rare and Endangered Mollusks. Malacologia 10: 9-22.

Strayer, D. L., J. A. Downing, W. R. Haag, T. L. King, J. B. Layzer, T. J. Newton \& S. J. Nichols, 2004. Changing perspectives on pearly mussels, North America's most imperiled animals. BioScience 54: 429-439.

Strayer, D. L., 2008. Freshwater Mussel Ecology: A Multifactor Approach to Distribution and Abundance. University of California Press, Berkeley, CA.

Strayer, D. L., 2012. Eight questions about invasions and ecosystem functioning. Ecology Letters 15: 1199-1210.

Strayer, D. L., 2014. Understanding how nutrient cycles and freshwater mussels (Unionoida) affect one another. Hydrobiologia. doi:10.1007/s10750-013-1461-5.

Subba Rao, N. V., 1989. Handbook Freshwater Molluscs of India. Zoological Survey of India, Calcutta.

Thomas, G. E., J. Taylor \& C. Garcia de Leaniz, 2014. Does the parasitic freshwater pearl mussel M. margaritifera harm its host? Hydrobiologia. doi:10.1007/s10750-013-1515-8.

Turgeon, D. D., A. E. Bogan \& E. V. Coan, 1988. Mollusks: Common and scientific names of aquatic invertebrates from the United States and Canada. American Fisheries Society special publication, American Fisheries Society, Bethesda, MD.

Turgeon, D. D., J. F. Quinn Jr., A. E. Bogan, E. V. Coan, F. G. Hochberg, W. G. Lyons, P. Mikkelsen, R. J. Neves, C. F. E. Roper, G. Rosenberg, B. Roth, A. Scheltema, M. J. Sweeney, F. G. Thompson, M. Vecchione \& J. D. Williams, 1998. Common and scientific names of aquatic invertebrates from the United States and Canada: Mollusks, Special Publication 26, 2nd ed. American Fisheries Society, Bethesda, MD.

Van Damme, D., 1984. The Freshwater Mollusca of Northern Africa: Distribution, Biogeography and Palaeoecology. W. Junk, Dordrecht.

Vaughn, C. C. \& C. C. Hakenkamp, 2001. The functional role of burrowing bivalves in freshwater ecosystems. Freshwater Biology 46: 1431-1446.

Vaughn, C. C. \& D. E. Spooner, 2006. Unionid mussels influence macroinvertebrate assemblage structure in streams.
Journal of the North American Benthological Society 25: 691-700.

Vaughn, C. C., D. E. Spooner \& H. S. Galbraith, 2007. Contextdependent species identity effects within a functional group of filter-feeding bivalves. Ecology 88: 1654-1662.

Vuković-Gačić, B., S. Kolarević, K. Sunjog, J. Tomović, J. Knežević-Vukčević, M. Paunović \& Z. Gačic, 2014. Comparative study of the genotoxic response of freshwater mussels Unio tumidus and Unio pictorum to environmental stress. Hydrobiologia. doi:10.1007/s10750-013-1513-x.

Walker, K. F., H. A. Jones \& M. W. Klunzinger, 2014. Bivalves in a bottleneck: taxonomy, phylogeography and conservation of freshwater mussels (Bivalvia: Unionoida) in Australasia. Hydrobiologia. doi:10.1007/s10750-0131522-9.

Wang, R., C. Li, J. Stoeckel, G. Moyer, Z. Liu \& E. Peatman, 2012. Rapid development of molecular resources for a freshwater mussel, Villosa lienosa (Bivalvia: Unionidae), using an RNA-seq-based approach. Freshwater Science 31: 695-708.

Watters, G. T., 1994. An Annotated Bibliography of the Reproduction and Propagation of the Unionoidea:(primarily of North America). Ohio Biological Survey, College of Biological Sciences, The Ohio State University, Colombus $\mathrm{OH}$

Williams, J. D., M. L. Warren, K. S. Cummings, J. L. Harris \& R. J. Neves, 1993. Conservation status of freshwater mussels of the United States and Canada. Fisheries 18: 6-22.

Zanatta, D. T. \& A. T. Harris, 2013. Phylogeography and genetic variability of the freshwater mussels (Bivalvia: Unionidae) ellipse, Venustaconcha ellipsiformis (Conrad 1836), and bleeding tooth, V. Pleasii (Marsh 1891. American Malacological Bulletin 31: 267-279.

Zieritz, A., J. Geist \& B. Gum, 2014. Spatio-temporal distribution patterns of three stream-dwelling freshwater mussel species: towards a strategy for representative surveys. Hydrobiologia. doi:10.1007/s10750-014-1897-2. 